\title{
4 \\ The changing pattern of economic growth
}

\section{Yiping Huang}

\section{STRONG GROWTH PERFORMANCE UNDER PREMIER ZHU}

Five years ago, when Zhu Rongji became premier, he launched a comprehensive and ambitious package of reforms, including improving the profitability of SOEs, reducing financial risks, and downsizing the government.

Wen Jiabao's first battle after becoming premier in early 2003 was to control the SARS epidemic. Now that the outbreak is effectively under control, the new government is likely to shift its focus to the reform agenda. The economic challenges facing the new government today are still similar to those of five years ago: lossmaking SOEs, huge bad loans, rising unemployment rate, and so on.

We should nonetheless not underestimate Zhu's contribution to the Chinese economy, made mainly in two areas-WTO entry and strong growth. China's successful conclusion of the negotiations on WTO accession, under Zhu's leadership, has set the direction and pace for future economic reforms.

China's growth performance over the past five years has been very impressive, particularly in comparison with growth of other Asian economies during the same period (Figure 4.1).

Over the past five years, most Asian economies' growth rates have been volatile because of the East Asian financial crisis in 1998 and then a significant slowdown in the US economy in 2001. China's GDP growth rate, however, has stayed between 
7.1 and 8 per cent. Interestingly, the growth performance of the Indian economy was also quite consistent during this period, suggesting that there might be a largeeconomy factor.

Some economists have questioned the reliability of China's official statistics. We believe, however, that even after taking into account possible data problems, China's GDP was still strong and steady.

What was the main contributor to China's extraordinary growth performance? This is one of the key questions. The most important question now is whether the growth pattern of recent times is likely to change or persist under the new leadership.

\section{GROWTH DRIVEN MAINLY BY STATE INVESTMENT}

China's fixed asset investment is still dominated by the state. There are two definitions of state sector investment.

Figure 4.1 Annual GDP growth, China, Hong Kong, Taiwan, Korea, Japan and India, 1998-2002 (year-on-year, per cent)

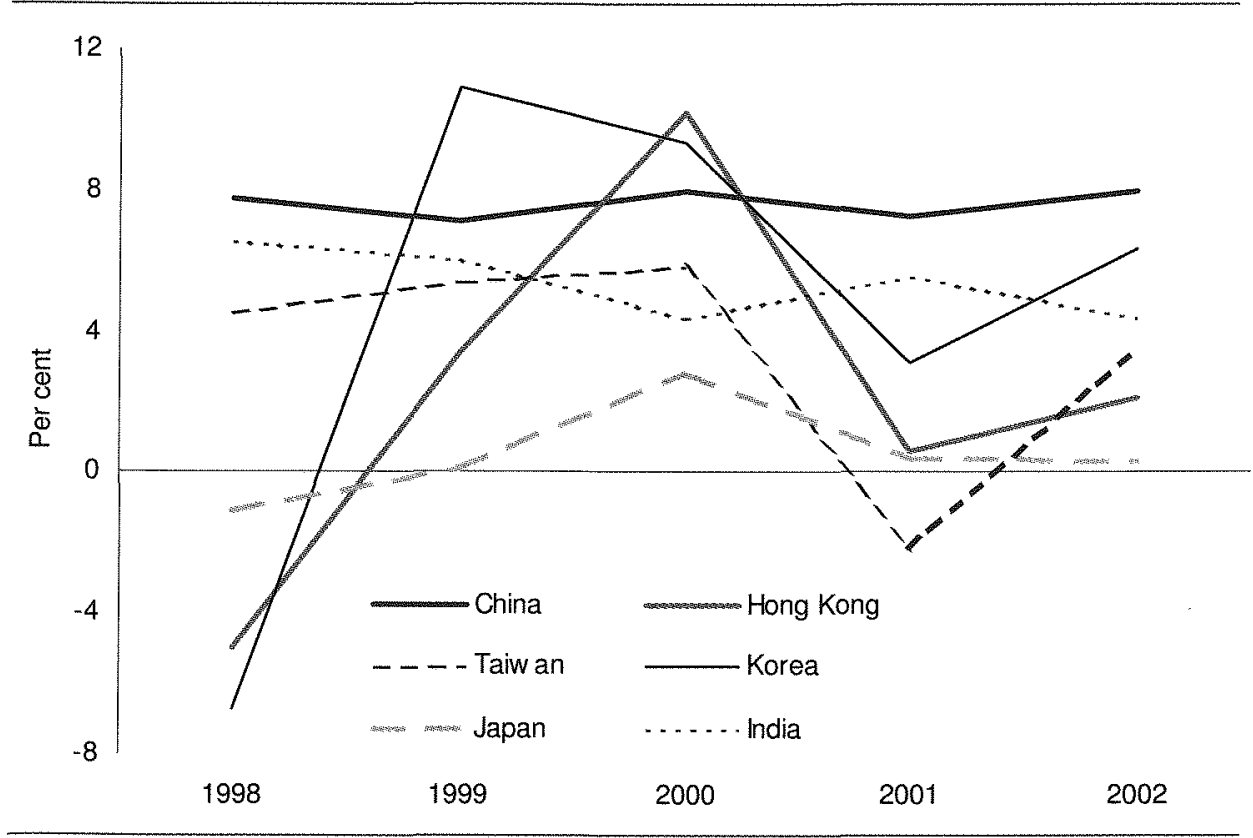

Source: CEIC. 
1 If only SOEs are considered, the share of the state sector in total investment was 48 per cent in 2002.

2 If the state sector is taken to include shareholding and listed companies controlled by the state, its share in total investment was 76.3 per cent in 2002.

This indicates that 'marketisation' proceeds much more slowly in investment than in the goods markets. There are three main channels for the financing of broadly defined state sector investment.

- Direct investment under the budget. Over the past five years, the government has issued RMB 650bn in treasury bonds to finance the construction of large infrastructure projects; another RMB 140bn is earmarked for direct investment in 2003.

- Financing of state-sponsored projects through either bank loans or bond issuance. The government has often called on the banks to provide loans for state-sponsored projects to supplement projects run directly by the state, and over the past five years an estimated RMB 3 trillion in loans has been provided for such projects.

- Bank loans for the state sector. While banks should in theory treat the state and non-state sectors equally in loan applications, in practice they still favour the state sector in their lending decisions, sometimes under pressure from local governments.

Broadly defined state sector investment may also include some investment by foreign investors in joint ventures. But this contribution is probably still limited. The

Table 4.1 Investment by state ${ }^{\star}$ and non-state sectors, 1997-2002 (per cent)

\begin{tabular}{ccccc}
\hline & $\begin{array}{c}\text { Growth of } \\
\text { total investment }\end{array}$ & $\begin{array}{c}\text { Growth of state } \\
\text { sector } \\
\text { investment }\end{array}$ & $\begin{array}{c}\text { Growth of } \\
\text { non-state sector } \\
\text { investment }\end{array}$ & $\begin{array}{c}\text { Share of state } \\
\text { sector in total } \\
\text { investment }\end{array}$ \\
1997 & 8.8 & 8.1 & 11.3 & 75.3 \\
1998 & 13.9 & 12.3 & 18.8 & 74.3 \\
1999 & 5.1 & 6.2 & 1.8 & 75.1 \\
2000 & 10.3 & 8.1 & 16.7 & 73.6 \\
2001 & 13.0 & 14.8 & 8.2 & 74.8 \\
2002 & 16.1 & 18.4 & 9.3 & 76.3 \\
\hline
\end{tabular}

Note: * Here state sector investment is taken to be fixed asset investment by SOEs and statecontrolled units.

Source: CEIC. 
average growth rate of actual FDI has only been 3.1 per cent during the past five years, and FDI accounted for 11 per cent of total investment.

How important is state sector investment for China's GDP growth? We can do some simple calculations. First, recall that GDP includes consumption, investment and net exports:

$$
G D P=C+I+\Delta X
$$

We can further decompose consumption into household and government consumption, and investment into state sector and non-state sector investment. Therefore, we can express GDP growth as a weighted average of growth in

1 household consumption

2 government consumption

3 state sector investment

4 non-state sector investment

5 net exports.

The weights used in this calculation are their respective shares in GDP over the past five years. State-related activity (government consumption and state sector investment) accounts for roughly 40 per cent of GDP, while net exports' share was only 2.8 per cent (see Figure 4.2).

Average GDP growth was 8.1 per cent in the period 1998-2002. Of this, 1.3 percentage points were contributed by government consumption, 2.7 by state investment, 3.4 by household consumption and 0.8 percentage points by non-state sector investment (Figure 4.2).

In other words, state sector-related activity accounted for half of GDP growth over the past five years (4 percentage points out of 8.1 per cent). This is the secret of China's growth success, but it is also one of our main concerns for the future.

\section{WHY THE CURRENT GROWTH PATTERN MAY NOT BE SUSTAINABLE}

\section{Investment-GDP ratio already unusually high}

In recent years, growth in fixed asset investment has accelerated and has consistently outpaced GDP growth. As a result, the investment-GDP ratio increased to the unusually high level of 42 per cent in 2002 from 34 per cent in 1997 (Figure 4.4). In other words, a smaller proportion of GDP was spent on consumption. How much longer can this continue? 
Investment-GDP ratios for many other Asian economies range between 20-30 per cent (Table 4.3).

Thus there is very little room for China to raise the share of investment in GDP further in the coming years, even if the government doesn't change its behaviour. In fact, the investment-GDP ratio is likely to fall, meaning that at some point in the future investment growth may be slower than GDP growth.

\section{Inefficiency of state investment}

State-dominated investment is often inefficient. China is no exception. In the past, when the government aimed at a minimum 7 per cent GDP growth, the inefficiency of the state sector investment became evident. When the proactive fiscal policy was introduced in 1998 and 1999, there were frequent reports of the poor quality of state-financed infrastructure projects.

More recently, there has been a visible improvement in construction quality, but low returns remain a general problem as projects are concentrated in less developed areas.

Figure 4.2 Average shares of various components of GDP, 1998-2002 (per cent)

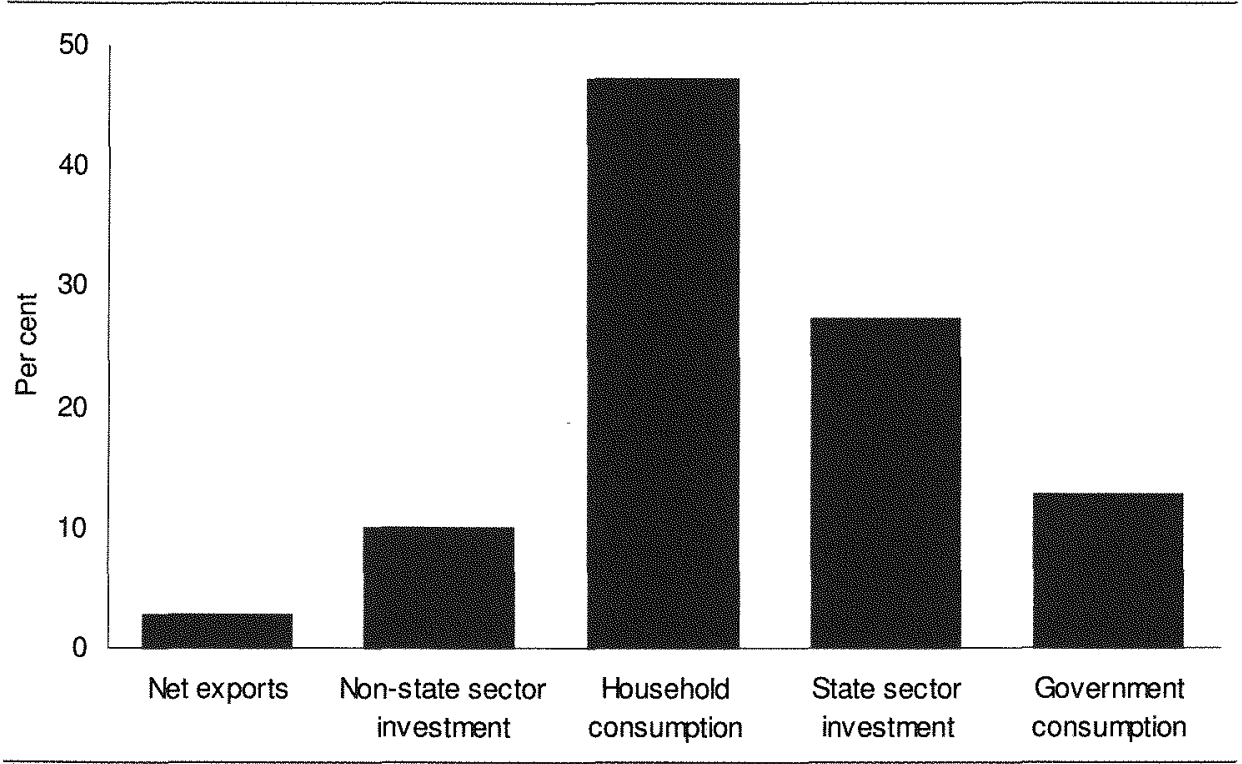

Source: Citigroup estimates. 
According to our estimates, while GDP growth has remained stable, the contribution of total factor productivity (TFP) to GDP growth has declined from 37 per cent in 1997 to 25 per cent in 2002 (Figure 4.5). In other words, growth has become increasingly reliant on the mobilisation of resources rather than on productivity improvement.

This is perhaps the strongest signal that China's past growth pattern may not be sustainable. This argument may sound odd given current strong growth momentum in China, but the former Soviet Union provides a good example. The Soviet Union's economic growth was attributable mainly to resource mobilisation, supported by central planning. In the early stages, particularly in the 1930s and 1950s, it was one of the world's fastest-growing economies. Such growth was not sustainable, however, because of the lack of productivity improvement.

Table 4.2 China and Asian economies: growth of GDP components and investment-GDP ratio, 2002 (per cent)

\begin{tabular}{lcccc}
\hline GDP & $\begin{array}{c}\text { Consumption } \\
\text { growth }\end{array}$ & $\begin{array}{c}\text { Gross capital } \\
\text { formation growth }\end{array}$ & $\begin{array}{c}\text { Investment-GDP } \\
\text { ratio }\end{array}$ \\
China & 8.0 & 8.8 & 16.0 & 42.2 \\
India & 5.5 & 6.1 & 3.8 & 24.2 \\
Korea & 6.3 & 6.2 & 4.3 & 24.3 \\
Malaysia & 4.2 & 6.4 & 8.8 & 30.1 \\
Taiwan & 3.5 & 1.5 & -2.0 & 18.3 \\
Thailand & 5.2 & 4.1 & 6.3 & 19.9 \\
\hline
\end{tabular}

Note: Data for India are for fiscal year 2001-02.

Source: CEIC and Citigroup estimates.

Table 4.3 Contingent liabilities

\begin{tabular}{lcc}
\hline & RMB & Per cent \\
& billion & of GDP \\
Accumulated public debt & 1,550 & 16.2 \\
Special T-bonds in 1998 & 270 & 2.8 \\
Costs for bank reform & 4,500 & 46.9 \\
Costs for Social Security Fund & 2,500 & 26.1 \\
Municipal contingent debt & 700 & 7.1 \\
External debt & 1,500 & 114.9 \\
Total & & \\
\hline
\end{tabular}

Source: Citigroup estimate. 
Figure 4.3 Contributions to GDP growth of various components, 1998-2002 (percentage points)

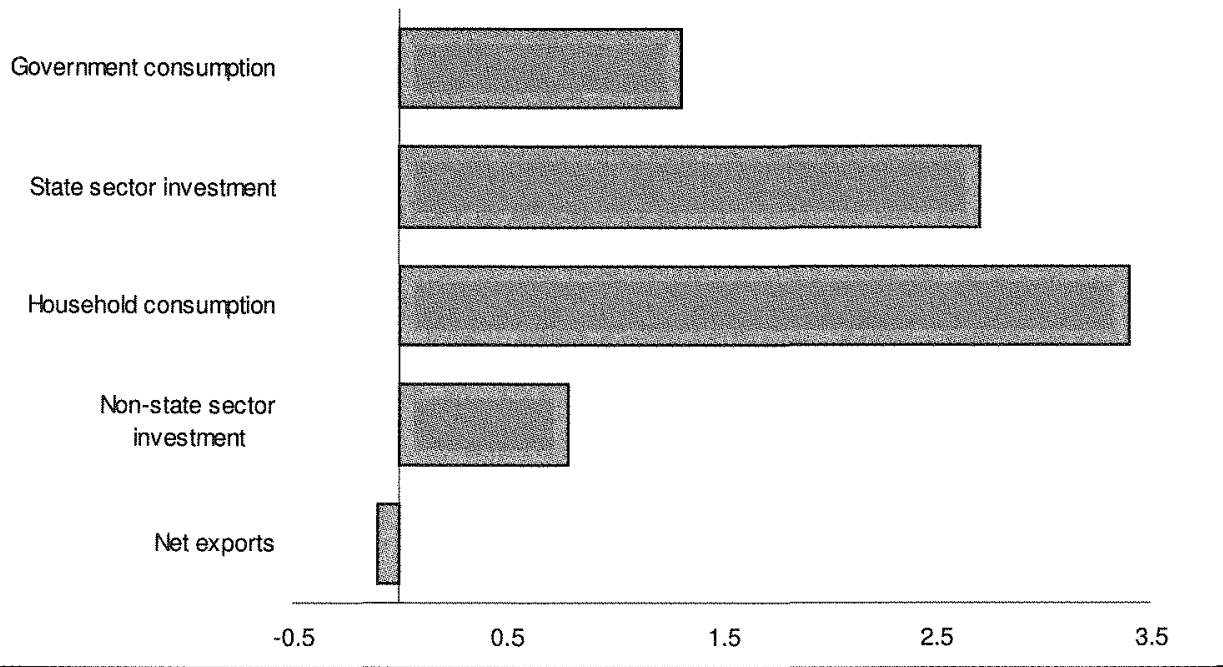

Source: Citigroup estimates.

Figure 4.4 High investment growth and rising investment-GDP ratio (per cent)

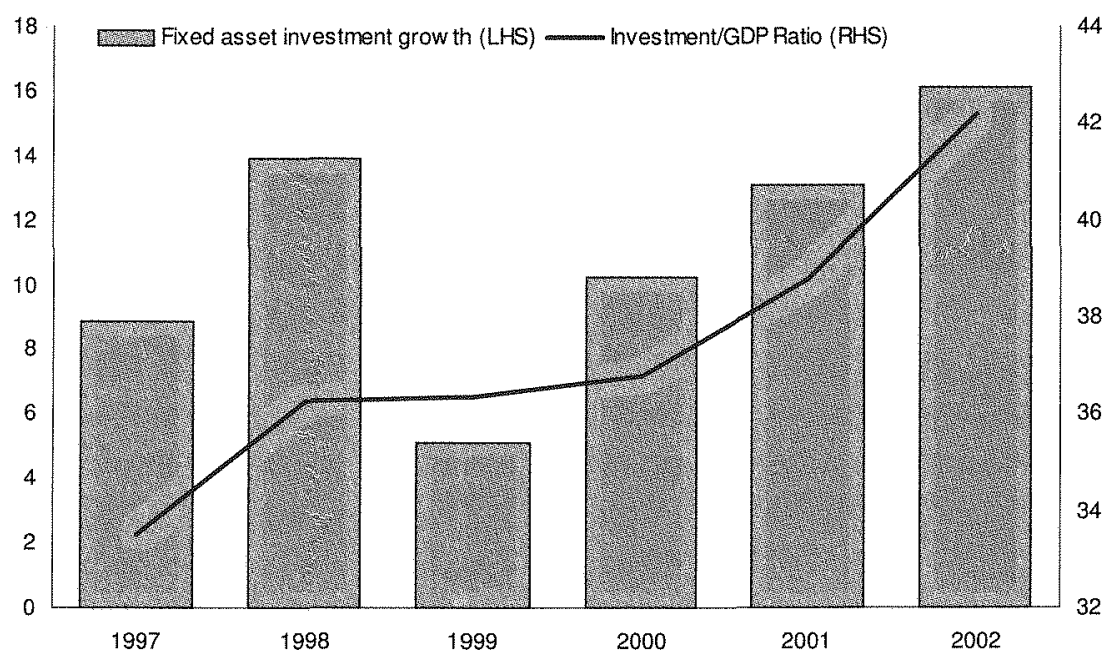

Source: CEIC. 
Usually, economists consider a growth pattern sustainable if TFP growth contributes more than one-third of GDP growth. According to this criterion, there is a large question mark over China's growth sustainability.

\section{Limited ability to obtain financing}

China's ability to maintain state investment-driven growth is also constrained by its ability to finance. The fiscal deficit grew from less than 1 per cent of GDP in 1997 to 3 per cent in 2002 as a result of the proactive fiscal policy in operation during the period (Figure 4.6).

While the current fiscal deficit is not necessarily dangerously high, the level of contingent liabilities is more alarming. Taking into account the potential cost of restructuring the banks and financing the social security fund, total liabilities are probably around 115 per cent of GDP. This is already comparable to those of Japan and some of the Scandinavian countries.

The government can continue to rely on bank lending to boost investment, as most of the banks are still state-owned. With a bad loan ratio above 20 per cent, however, the banks themselves are also under enormous pressure to improve asset quality.

\section{Accelerated boom-and-bust cycles for industries}

Another side-effect of state investment-driven growth is a build-up of inventories. Indeed, since the beginning of 2003 , inventories have been accumulating rapidly in the electronics and communication, and transport equipment sectors.

A consequence of this is that the growth of the whole economy is always dependent on a small number of industries and the boom-and-bust cycles of such industries are accelerated when state investment is involved. Since the beginning of economic reform, we have already seen several cycles.

- In the mid 1980s, the textile industry was the growth engine, but excess capacity became a serious problem, and later the government ordered the closure of many textile factories across the country.

- In the early 1990s, the electronics industry (particularly producers of televisions, refrigerators, and so forth) became a hotspot, but in the late 1990s price wars became endemic in the markets. 
- From 1998, the government promoted the property sector as one of the main growth drivers. In late 2002, however, policymakers voiced concerns about a possible bubble in the market and, in mid June this year, the central bank introduced a series of new measures to cool property investment.

- Now, the only growth engine is the automobile industry. Growth in car production should stay at around 100 per cent this year. Our question is how long it will be before collapse in this market, too, becomes necessary or inevitable.

Of course, both private sector investment and FDI have also played important roles in these industry booms. But policies designed to encourage pillar industriesparticularly with the involvement of state investment, which usually means less attention paid to efficiency and returns-are also responsible for the accelerated boom-and-bust cycles. This often leads to the waste of scarce investment resources.

Figure 4.5 Annual GDP growth and share of TFP in GDP growth, 1997-2002 (per cent)

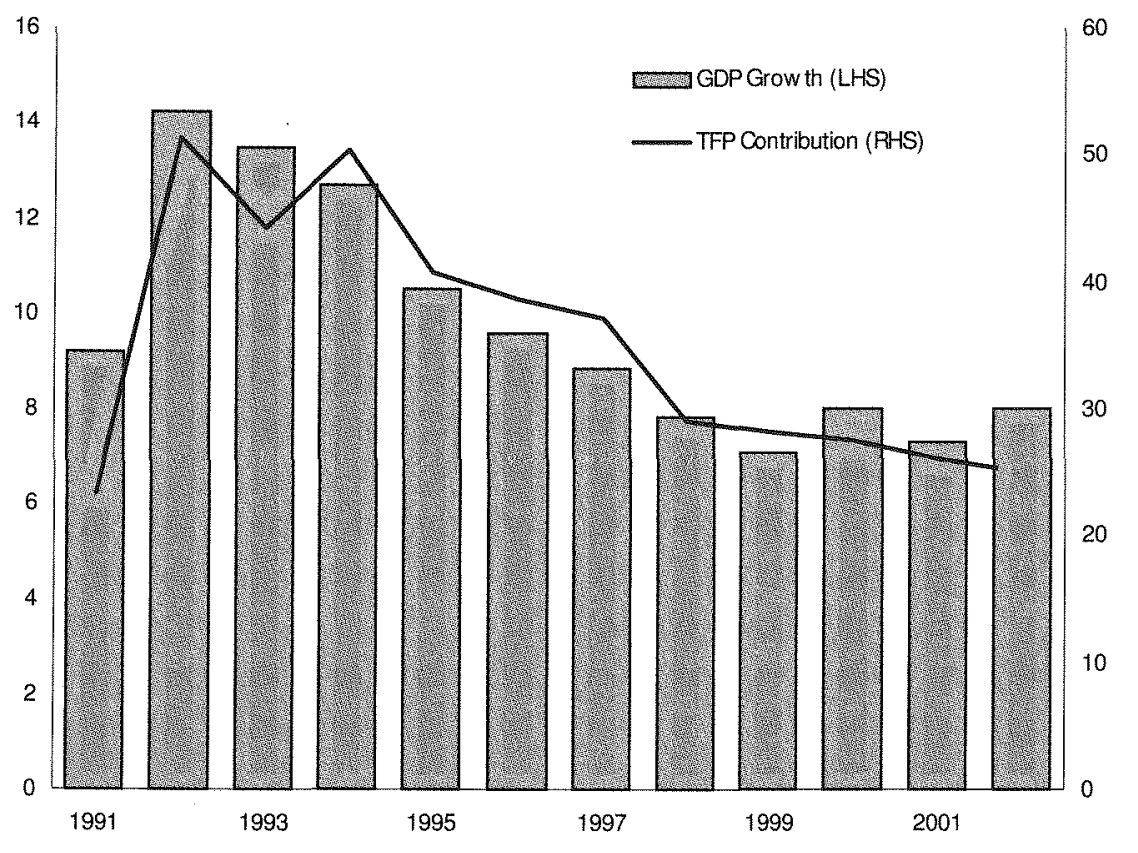

Source: Citigroup estimates. 


\section{PROMOTING PRIVATE SECTOR INVESTMENT AND IMPROVING INVESTMENT EFFICIENCY}

\section{Long-term growth potential}

In the absence of any major disruption, China should be able to maintain GDP growth at 7.5 per cent per annum for at least another 10 years. Only India and Malaysia can match this potential.

Our optimism is based mainly on China's expected ability to achieve productivity growth. On one hand, the expected structural reforms, particularly those to which China is committed in the agreements on WTO accession, should lead to more efficient use of resources. On the other hand, China is still a relatively poor country with GDP per capita at US $\$ 1,000$. In other words, China is far from the world's economic

Figure 4.6 China's fiscal deficits, 1997-2002 (RMB billion, per cent)

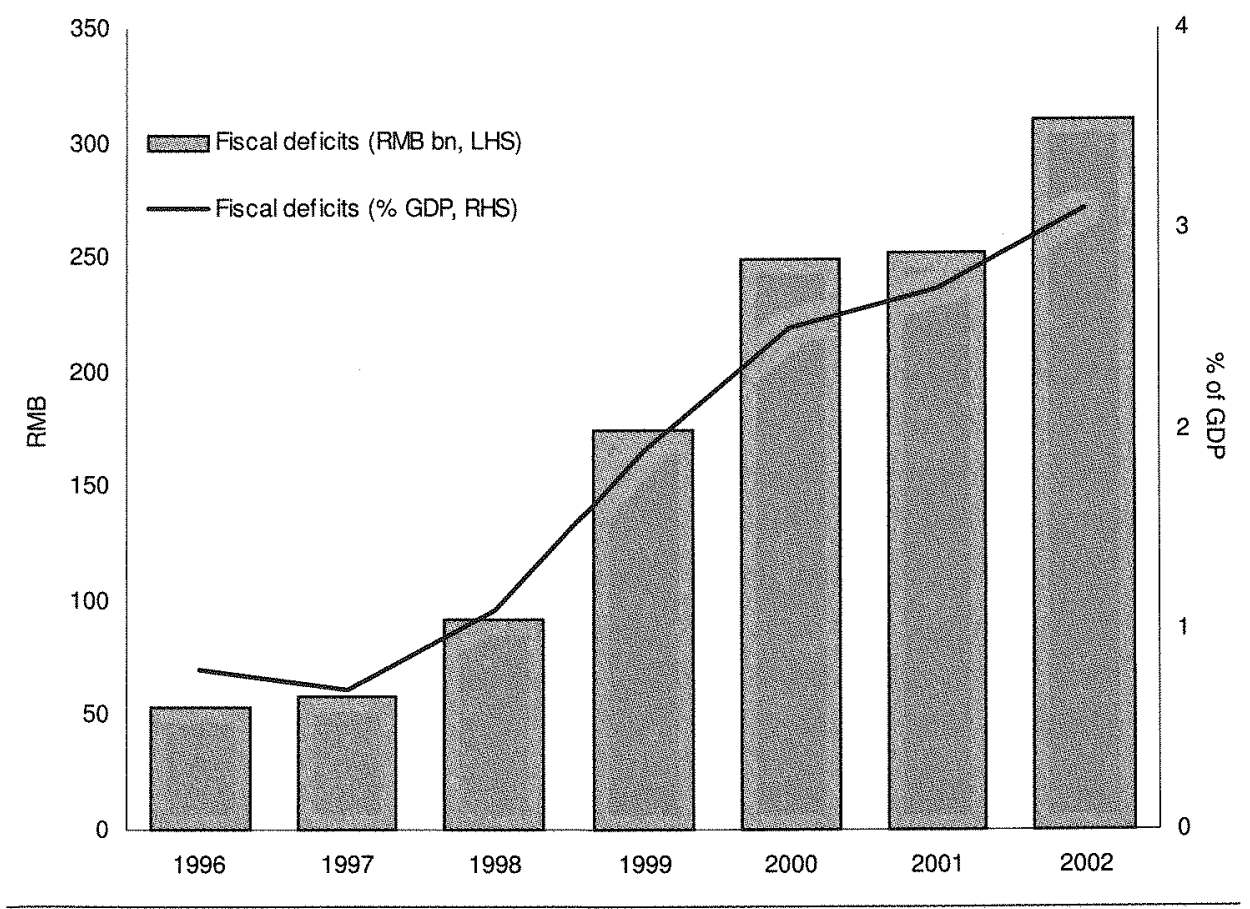

Source: Citigroup estimates. 
and technological frontiers, which makes the growth highly visible as it catches up. This is typically described as the 'advantage of backwardness' in growth literature.

\section{Promoting private sector investment}

Before this long-run growth potential can materialise, China will need to change its growth pattern. At the centre of this transformation will be the rise of private sector investment. The share of the state sector in overall investment should decrease significantly from the current 75 per cent as a natural part of the process of structural reform. Specifically, the following changes need to be made to ease such a transition

- The government needs to cut back on budget-supported investment projects and loan-financed state sector investment programs.

- The state-owned commercial banks need to extend more loans to the more profitable non-state sectors.

- The authorities need to create more favourable conditions for private enterprises to access the capital markets, both stock and bond markets.

Most importantly, however, policymakers need to abandon their obsession with achieving GDP growth rates above 7 per cent. In 1998, Zhu Rongji's government set 7 per cent as its GDP growth target. The result was that every province reported GDP growth of more than 7 per cent that year. The government recognised the political incentive for local leaders to exaggerate their growth performance and thus gave up setting any growth target after that. Nonetheless, the critical level of GDP growth remains 7 per cent in many policymakers' minds. Whenever GDP growth falls toward this level, the government tries to support growth, mainly through increased fiscal spending and state sector investment. The implicit reasoning is that slowing growth would lead to higher unemployment, which has broader social and political implications. In reality, however, state-backed growth has not had the desired effect as far as job creation is concerned.

Once more efficient private sector investment starts to take a more dominant role, the pressure for continued rapid investment growth should begin to ease off. Indeed, over time, sustainable rapid GDP growth may be compatible with a slowly declining investment/GDP ratio.

\section{Bullish on consumption in the long run}

A falling investment-GDP ratio is equivalent to a rising consumption-GDP ratio. This is the first reason we believe that in the long run China's GDP growth will be driven by consumer spending. 
The second reason is that we are confident that China's high growth is sustainable, and thus that household income is likely to increase rapidly. Assuming GDP growth of 7.5 per cent and population growth of 1.5 per cent, China should easily be able to achieve 6 per cent growth in per capita income. Chinese households' purchasing power should grow even faster if the renminbi appreciates. Something similar has happened in most newly industrialised East Asian economies over past decadesa strong economy leads to currency appreciation, and income catches up with GDP growth faster than predicted.

Figure 4.7 Growth of inventories by industry, end-April 2003 (per cent change, year-on-year)

Petroleum processing \& coking

Eectronic \& communication equipment Chemical fibre industry Transportation equipment Ferrous metals of smelting \& pressing Metal products Plastic products Raw chemical materials \& products Food manuf acturing Textile industry Ordinary machinery Garment \& other Fibre products Furniture manufacturing Eectric machinery \& equipment Medical \& pharmaceutical products Petroleum \& natural gas extraction Rubber products Coal mining $\&$ dressing Beverage manufacturing Tobacco processing Non ferrous metal mining \& dressing

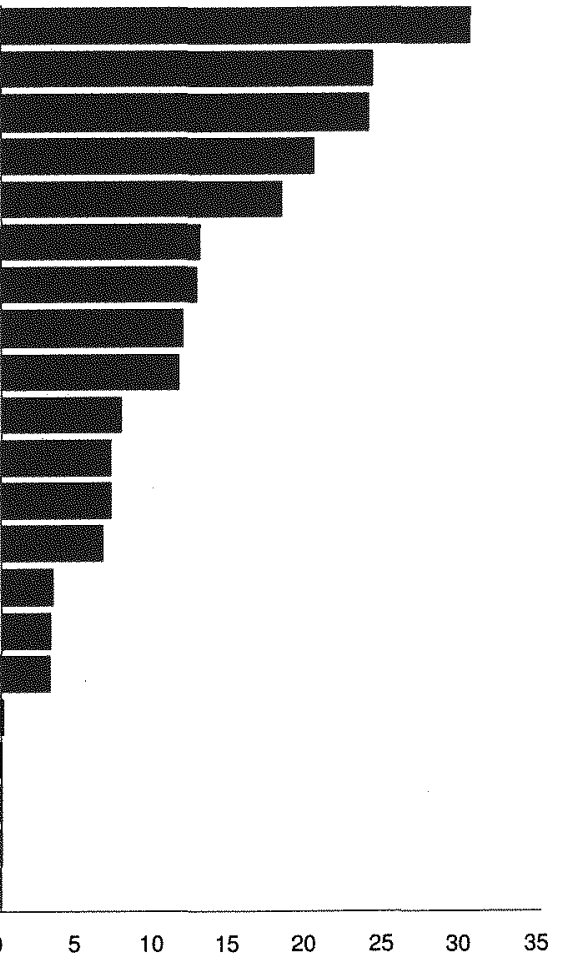

Source: Citigroup. 
Last, given China's family planning policy, it is also likely to have a more severe problem with population aging than other populous Asian economies. Over time, this will lower households' savings ratio.

\section{NEAR-TERM OUTLOOK AND IMPLICATIONS}

Reforms under the new government are likely to facilitate the promotion of privatesector investment. Specifically, the new administration has established two new organisations

1 The China Banking Regulatory Commission (CBRC) aims at the speedy restructuring of the state-owned commercial banks. This should lead to bank lending being guided more by commercial considerations than by government fiat.

2 The State-Owned Asset Supervision and Administration Commission (SASAC) takes under its control about 196 large companies with assets worth RMB 6.9 trillion (US $\$ 834$ billion). It is likely to speed the restructuring process, through public listings, foreign strategic investors. We expect the establishment of the SASAC to lead to a new wave of privatisations nationwide.

Growth will continue to depend on state sector investment, FDI and exports in the near term

No immediate end is foreseeable to the economy's heavy reliance on state sector investment for growth

- For one thing, the SARS epidemic probably strengthened rather than weakened the state investment mechanism. As some officials are worried about the implications of the SARS outbreak for growth, the government may consider increasing stimulus measures to support economic growth.

- Since 2002, the state banks have become more aggressive in extending loans to the corporate sector, particularly private enterprises. But this process may be reversed. China recently revealed a number of cases of corruption among senior bank officials, all involving high-profile private entrepreneurs. This is likely to discourage banks from lending to the private sector. For most bank managers, the same old principle still applies-if a loan turns bad with an SOE, it may be a bad commercial decision; but if a loan turns bad with a private enterprise, it may be a criminal act. 
Table 4.4 Selected Asian economies, long-term growth potential (per cent)

\begin{tabular}{lccc} 
& Avg. output growth & \multicolumn{2}{c}{ Long-term growth potential } \\
China & $1960-99$ & Citigroup & Consensus \\
India & 9.8 & 7.5 & 7.3 \\
Indonesia & 5.8 & 7.5 & 6.4 \\
Korea & 7.1 & 5.0 & 5.0 \\
Malaysia & 9.8 & 5.5 & 4.8 \\
Philippines & 8.6 & 7.0 & 6.2 \\
Singapore & 4.8 & 5.0 & n.a. \\
Thailand & 10.5 & 6.0 & 5.5 \\
Taiwan & 8.7 & 4.5 & 4.0 \\
Japan & 10.7 & 5.0 & 4.4 \\
United States & 6.2 & 2.7 & 2.0 \\
& 4.3 & 3.7 & 3.4 \\
\hline
\end{tabular}

Source: Adapted from Citigroup, 2002. Asian Economic Outlook and Strategy: accounting for growth, Citigroup, Hong Kong, 28 March.

Table 4.5 Citigroup estimates of long-term growth potential, selected Asian economies

\begin{tabular}{lccc}
\hline & $\begin{array}{c}\text { Young workers' } \\
\text { share in total } \\
\text { labour force (\%) }\end{array}$ & $\begin{array}{c}\text { Share of aged } \\
\text { population (\%) }\end{array}$ & $\begin{array}{c}\text { Age dependency } \\
\text { ratio }\end{array}$ \\
China & 60.3 & 9.0 & 0.5 \\
1990 & 44.6 & 11.8 & 0.5 \\
$2010 \mathrm{E}$ & & & \\
India & 61.4 & 8.0 & 0.8 \\
1990 & 57.4 & 8.4 & 0.6 \\
$2010 \mathrm{E}$ & & & 0.7 \\
Indonesia & 62.1 & 6.3 & 0.6 \\
1990 & 55.1 & 8.9 & 0.6 \\
$2010 \mathrm{E}$ & & & \\
\hline
\end{tabular}

Notes: Young workers are those aged between 15 and 39 ; the aged population includes those above 60 . The age dependency ratio is the proportion of the population of under 15 and above 60 to that aged 15-60.

Source: World Bank, various. World Population Projections, World Bank, New York. 
- Consumption will probably recover, as SARS is under control. But could household consumption become a major driver in the near term? Probably not. Over the past five years, growth in retail sales has fluctuated between 6-10 per cent, much lower than during the pre-1998 period (Figure 4.8).

The reason consumers became more cautious in 1998 was that accelerated structural reforms, including reforms to the social welfare, education and medical insurance systems, significantly increased uncertainty. Although income growth was high, households saved more money in the bank in anticipation of reduced support from the state in coming years. This explains why bank deposits have grown at around 20 per cent year-on-year recently.

This situation is unlikely to change before the social security system reform is completed, and will not happen soon.

Figure 4.8 Retail sales, 1994-2003 (year-on-year, per cent change)

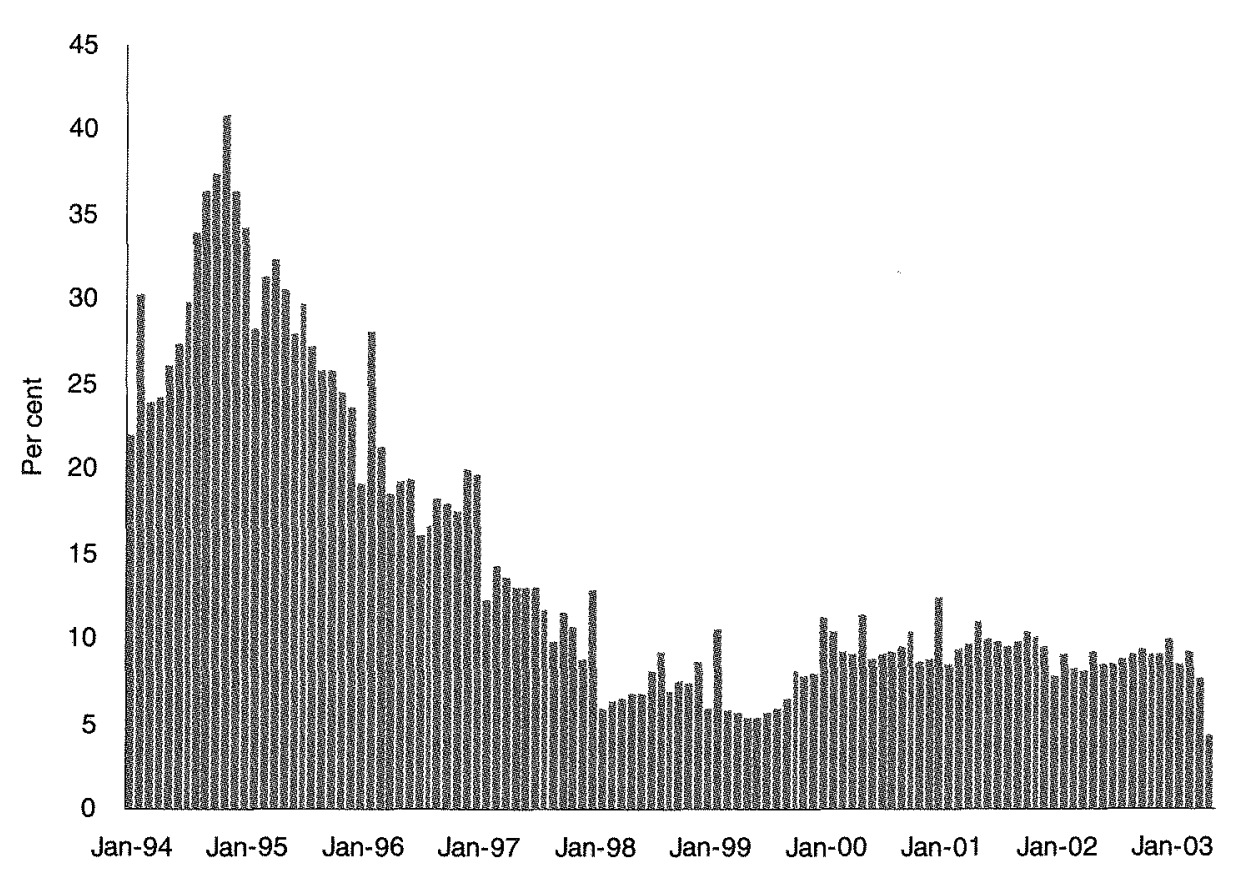

Source: CEIC. 
Retail sales are growing faster in the cities than in the countryside. This supports our view that growth is generally stronger in high-income household spending than in low-income household spending. However, if we look more closely at high-income household expenditure, there is a strong concentration in a small number of goods, particularly housing, automobiles and tech products. This pattern will probably continue in the coming years.

Mild monetary tightening possible but no change likely in exchange rate policy change

There are some concerns that the economy is overheating. The producer price index (PPI) has stayed around 4 per cent year-on-year in recent months, compared with negative growth in 2002. The main increase, however, came from the PPIs for

Figure 4.9 Bank deposits, 1998-2003 (year-on-year per cent change)

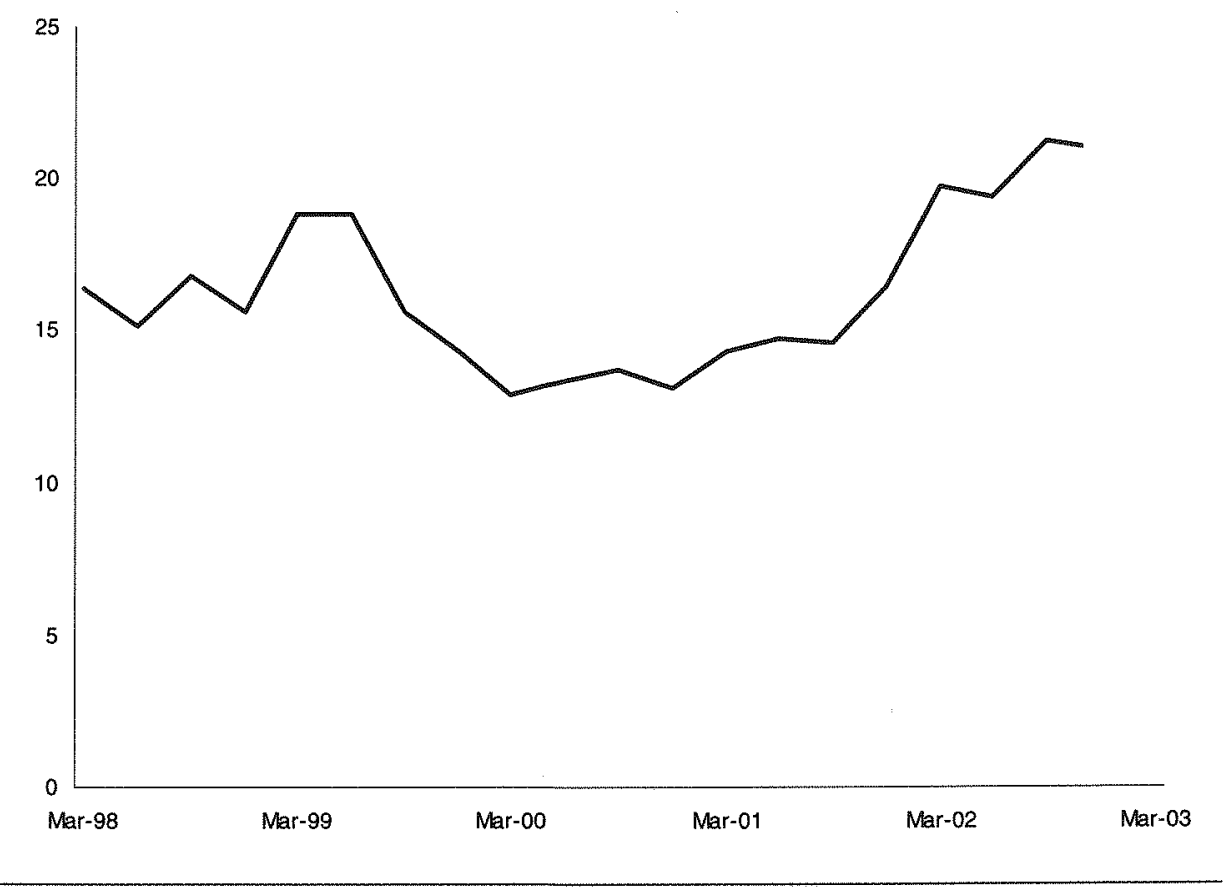

Source: CEIC. 
Figure 4.10 Consumer Price Index and money supply (M2) growth (per cent year-on-year)

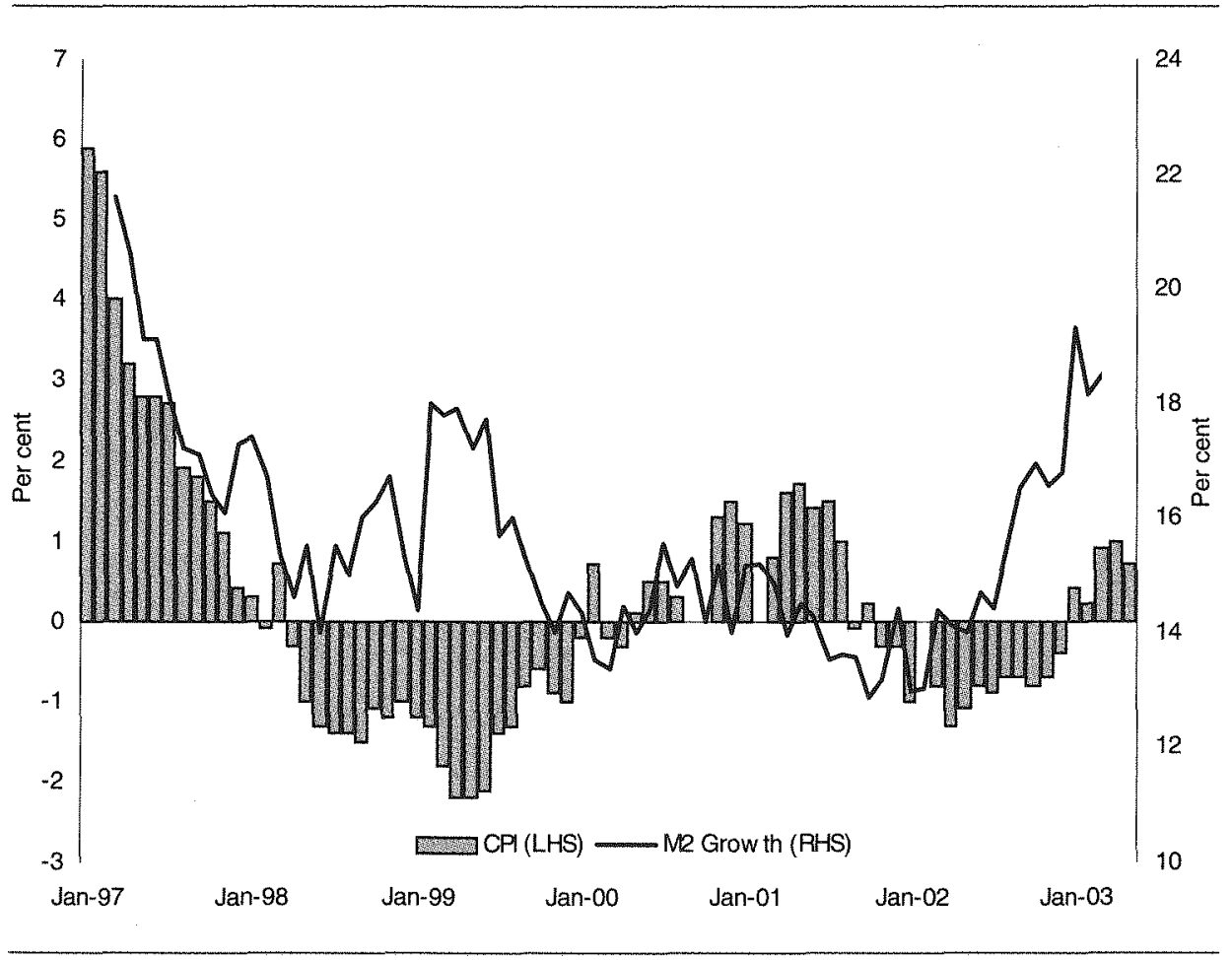

Source: CEIC.

heavy industry (up 8-10 per cent year-on-year in February-April) and producer goods (up 5-7 per cent). This is probably related to the high prices for energy and basic materials. In fact, the PPI for light industry and consumer goods is still falling.

But the acceleration of money supply (M2) growth in recent months is very clear (Figure 4.10). This probably reflects the PBOC's efforts to fight deflation since late 2002. With the currency probably undervalued, the central bank should be able to expand its money supply significantly. Also, the CPI returned to positive territory in 2003.

Concerns about possible overheating may lead to some mild monetary tightening; and the central bank has indicated that it might raise the provision requirements for commercial banks. The central bank is likely to be very cautious, given that the 
economy is newly out of deflation and the near-term outlook for the economy is not very clear. If there is any tightening in the near term, it is likely to be mild.

Another issue that has drawn attention lately is exchange rate policy. Some analysts have even predicted that the currency will appreciate by 2.5 per cent within six months.

Some flexibility will eventually be introduced to the exchange rate regime, but this probably will not occur any time soon.

Two crucial conditions will need to be in place before Chinese policymakers begin to consider widening the band

- a stable outlook for the economy, including exports

- a significant ratcheting up of US pressure (lobbying by Japanese officials does not seem to carry much weight in Beijing).

US government officials have on various occasions recently mentioned a possible need for Yuan revaluation, suggesting that US policymakers probably already have the issue in their sights. This does not yet appear to be a top policy priority for the United States in bilateral relations.

More importantly, Chinese policymakers are still more concerned about the condition of the domestic economy. First, it is not yet clear whether the SARS outbreak will have any delayed effect on the economy, particularly on exports, in coming months. Second, the unemployment situation appears to have deteriorated lately, with at least one-third of new university graduates failing to find jobs. Finally, there are also concerns that CNY appreciation might lead to renewed downward pressure on wages and prices.

It is unlikely that Yuan revaluation will happen in 2003. If all situations develop favourably, the earliest possible time for a policy change would be early 2004 . Even then, a major effect on the foreign exchange market is not likely, as the new band will probably only be $+/-3$ per cent. 